\title{
PENELITIAN ILMIAH BATAS WILAYAH LAUT INDONESIA BERDASARKAN KONVENSI HUKUM LAUT PBB TAHUN 1982
}

\author{
Tommy Hendra Purwaka \\ Fakultas Hukum Universitas Katolik Indonesia Atma Jaya \\ Gd. I.J. Kasimo, Lt. 3, Jl. Jenderal Sudirman 51, Jakarta 12930 \\ email : tommy.hendra@atmajaya.ac.id
}

\begin{abstract}
According to UNCLOS of 1982, Indonesia has sovereignty over internal waters, archipelagic waters, and twelve nautical miles territorial sea. It has also sovereign rights over 200 nautical miles exclusive economic zones (EEZ) and continental shelves. It has not yet determined contiguous zones beyond its territorial sea. In this respect, it has duty to delimit and map maritime boundaries of its waters based on the best scientific data produced by marine scientific research. Marine scientific research, therefore, plays a very important role in the delimitation of maritime boundaries of Indonesian waters.
\end{abstract}

Keywords: UNCLOS, Scientific Research, Maritime Bounderies Delimitation

\begin{abstract}
Abstrak
Indonesia berdasarkan Konvensi Hukum Laut 1982 memiliki kedaulatan atas perairan pedalaman, perairan kepulauan, dan laut teritorial 12 mil laut diukur dari garis pangkal kepulauan. Indonesia juga mempunyai hak-hak berdaulat atas zona ekonomi eksklusif 200 mil laut (ZEE) dan landas kontinen. Dalam kaitan ini, Indonesia belum menetapkan zona tambahan di luar laut teritorial. Sehubungan dengan itu, Indonesia wajib menetapkan dan memetakan batas-batas wilayah lautnya berdasarkan data terbaik yang dihasilkan oleh penelitian ilmiah kelautan. Dengan demikian penelitian ilmiah kelautan memegang peranan sangat penting dalam penetapan dan pemetaan batas-batas wilayah laut Indonesia.
\end{abstract}

Kata kunci: UNCLOS, Penelitian Ilmiah, Penyelesaian Batas Laut

\section{A. Pendahuluan}

Menurut UNCLOS 1982, ${ }^{\prime}$ negara kepulauan Indonesia memiliki kedaulatan (sovereignty) atas perairan pedalaman (internal waters), perairan kepulauan (archipelagic waters), dan laut teritorial $12 \mathrm{mil}$ (12 $\mathrm{nm}$ territorial sea), serta hak-hak berdaulat (sovereign rights) di zona ekonomi eksklusif $200 \mathrm{mil}(200 \mathrm{~nm}$ exclusive economic zone), dan landas kontinen (continental shelf). ${ }^{2}$ Satu kesatuan wilayah laut dan daratan pulau-pulau dari negara kepulauan Indonesia perlu diisi dengan kegiatan pembangunan agar terwujud makna wilayah laut sebagai faktor pemersatu, bukan faktor pemisah, wilayah kepulauan Indonesia. ${ }^{3}$

Pelaksanaan pembangunan kelautan memerlukan ketegasan batas-batas wilayah laut yang berada di bawah kedaulatan dan jurisdiksi Indonesia agar supaya dapat berlangsung secara

\footnotetext{
${ }^{1}$ Lihat Bab IXA, Pasal 25A UUD 1945, UU Nomor 17 Tahun 1985 jo. UU Nomor 19 Tahun 1961, UU Nomor 6 Tahun 1996 jo. UU Nomor 4 prp Tahun 1960, UU Nomor 1 Tahun 1973, dan UU Nomor 5 Tahun 1983.

${ }_{2}^{2}$ Mochtar Kusumaatmadja, 1995, Bunga Rampai Hukum Laut, Bandung, Pusat Studi Wawasan Nusantara, Hukum, dan Pembangunan, hlm. 45-64. Lihat juga Adi Sumardiman, et. al., 1982, Wawasan Nusantara, Jakarta, Surya Indah, hlm. 29-62. Lihat juga Mochtar Kusumaatmadja, 1995, Hukum Laut Internasional, Bandung, Pusat Studi Wawasan Nusantara, Hukum, dan Pembangunan, hlm. 29-53 yang menguraikan tentang kekuasaan negara atas laut yang berbatasan dengan pantainya.

${ }_{3}^{3}$ Antonius P.S. Wibowo, 2000, Menyambut Sistem Kelautan Indonesia Baru, Jakarta, Atma Jaya, hlm. 1-28. Lihat juga Tommy Hendra Purwaka, "Paradigm Shift in the Implementation of the Law of the Sea in Indonesia", Indonesian Journal of International Law, Volume 8 Number 1 October 2010, hlm. 115-121.
} 
efektif. ${ }^{4}$ Sebagian besar batas-batas wilayah laut Indonesia belum ditetapkan. Batas wilayah laut antara Indonesia dan negara tetangga juga belum selesai seluruhnya. Penetapan batas-batas wilayah laut tersebut harus didasarkan pada data terbaik hasil penelitian ilmiah kelautan. ${ }^{5}$ Oleh karena itu, tulisan singkat ini akan membahas penelitian ilmiah kelautan yang wajib dilakukan oleh Indonesia dalam rangka penetapan batas-batas wilayah laut Indonesia.

\section{B. Pembahasan}

\section{Lingkup Bahasan}

Lingkup bahasan tentang penelitian ilmiah batas wilayah laut Indonesia meliputi penelitian tentang garis pangkal, wilayah laut Indonesia, wilayah laut perbatasan, dan wilayah laut daerah, serta wilayah kepulauan. ${ }^{6}$ Penelitian ilmiah kelautan ini sebaiknya dilakukan secara berkelanjutan untuk mengantisipasi perubahan-perubahan yang terjadi yang mempengaruhi tata letak titik-titik terluar dari pulau-pulau terluar dan garis batas wilayah laut Indonesia.

\section{Garis Pangkal Kepulauan}

Garis pangkal kepulauan Indonesia memang telah ditetapkan dan dipetakan. Namun demikian, perubahan-perubahan yang terjadi karena fenomena alam seperti tsunami ${ }^{7}$ dan gempa bumi serta peningkatan permukaan laut karena pemanasan global dapat mempengaruhi posisi garis pangkal kepualauan. Perubahan politik seperti lepasnya
Timor Timur, ${ }^{8}$ Pulau Ligitan-Sipadan ${ }^{9}$ kemungkinan juga dapat mengubah letak garis pangkal kepulauan. Garis pangkal kepulauan di wilayah laut perbatasan yang batas-batasnya belum terselesaikan kelihatannya perlu diadakan pengecekan kembali. Penelitian ilmiah kelautan sebaiknya difokuskan pada kondisi-kondisi geografis, oceanografis, dan geologis dari titik-titik terluar dari pulau-pulau terluar Indonesia untuk memperkuat posisi garis pangkal kepulauan yang telah ditetapkan berdasarkan Pasal 47 ayat (1) UNCLOS. ${ }^{10}$ Penelitian juga perlu memperhatikan titik-titik referensi di darat sebagai penjamin posisi titik-titik terluar tidak berubah walaupun titik-titik terluar tersebut tidak lagi selalu ada di atas permukaan laut [Pasal 47 ayat (4) UNCLOS] ${ }^{11}$ syarat-syarat penarikan garis pangkal kepulauan [Pasal 47 ayat (2) UNCLOS], penggambaran garis pangkal [Pasal 47 ayat (3) UNCLOS], larangan menutup ZEE atau laut lepas [Pasal 47 ayat (5) UNCLOS], ${ }^{12}$ hak-hak tradisional di perairan nusantara [Pasal 47 ayat (6) UNCLOS], dan pemetaan garis pangkal kepulauan [Pasal 47 ayat $(7,8,9)$ UNCLOS].

\section{Wilayah Laut}

Penelitian ilmiah kelautan terhadap wilayah laut Indonesia hendaknya difokuskan pada perairan pedalaman, perairan kepulauan, laut teritorial, zona tambahan, ${ }^{13}$ zona ekonomi eksklusif (ZEE), dan landas kontinen. ${ }^{14}$ Perairan pedalaman adalah wilayah laut yang berada di sisi dalam garis pangkal

\footnotetext{
${ }^{4}$ Adi Sumardiman, 1992, Wilayah Indonesia dan Dasar Hukumnya, Jakarta, Pradnya Paramita, hlm. 4-10, 58-80.

5. Penafsiran analogis dari Pasal 61 ayat (2) UNCLOS: "The coastal State, taking into account the best scientific evidence [data] available to it, shall ensure through proper conservation...". Lihat juga R.R. Churchill and A.V. Lowe, 1999, The Law of the Sea, Manchester, Manchester University Press, hlm. 400 yang mengatakan:"Adequate and effective [marine] scientific research is a basic precondition for [the delimitation of maritime boundaries and] the rational exploitation of the sea's resources".

${ }^{6}$ Untuk lebih memahami apa itu penelitian kelauatan, garis pangkal dan jenis-jenis wilayah laut (ocean space) menurut hukum laut internasional lihat R.R. Churchill and A.V. Lowe, 1999, The Law of the Sea, Manchester, Manchester University Press, hlm. 31-101, $118-180$.

${ }^{7}$ Tsunami yang terjadi pada tanggal 26 Desember 2004 di Samudera Hindia di selatan Aceh telah mengubah tata letak geografis dan geologis wilayah pesisir selatan Aceh dan bahkan berdampak luas sampai ke Sri Langka.

${ }^{8}$ Timor Timur lepas dari Indonesia dan menjadi negara merdeka Timor Leste yang membawa konsekuensi perlunya segera menetapkan batas wilayah laut antara Indonesia dan Timor Leste.

${ }_{9}^{9}$ Pulau Ligitan dan Pulau Sipadan telah diputuskan oleh ICJ sebagai pulau-pulau Malaysia yang menimbulkan masalah Ambang Batas Laut di sekitar Pulau Unarang yang kaya akan sumber daya minyak dan gas bumi (masalah Ambalat) yang mungkin akan diklaim oleh Malaysia sebagai wilayahnya sebagai akibat pengukuran batas landas kontinen Malaysia dari ke dua pulau tersebut.

${ }^{10}$ Achmad Jusnadi, Herie Saksono dan Suryo Sakti, 2005, Platform Penanganan Permasalahan Perbatasan Antar Negara, Jakarta, Direktorat Wilayah Administrasi dan Perbatasan, Direktorat Jenderal Pemerintahan Umum, Departemen Dalam Negeri, hlm. 33-36.

${ }^{11}$ Jason M. Patlis, et. al., 2005, Menuju Harmonisasi Sistem Hukum Sebagai Pilar Pengelolaan Wilayah Pesisi Indonesia, Jakarta, KPPN/BAPPENAS, DKP, DH\&HAM, dan USAID, hlm. 117-120.

${ }^{12}$ Lihat, loc. Cit.., hlm. 77 perihal Indonesia telah melakukan penyesuaian garis pangkal kepualauan di Laut Natuna dan sekitarnya melalui PP Nomor 61 Tahun 1998 yang dikenal dengan PP tentang penutupan kantung Natuna.

${ }_{13}^{13}$ Mochtar Kusumaatmadja, 1995, Masalah Lebar Laut Teritorial Pada Konperensi-Konperensi Jenewa (1958 dan 1960), Bandung, Pusat Studi Wawasan Nusantara, Hukum, dan Pembangunan, hlm.259-264, 272-278, menjelaskan pentingnya laut teritorial dan jalur tambahan bagi negera-negara peserta Konperensi Hukum Laut Jenewa 1958 dan 1960.

${ }^{14}$ J.R.V. Prescott, 1985, The Maritime Political Boundaries of the World, London, Methuen, hlm. 36-80.
} 
Tommy Hendra P., Penelitian Ilmiah Batas Wilayah Laut Indonesia

kepulauan mengarah ke daratan, sepertiteluk, muara sungai, dan pelabuhan [Pasal 50 jo. Pasal 8, Pasal 9, Pasal 10, dan Pasal 11 UNCLOS]. Penelitian ilmiah kelautan terhadap batas-batas perairan pedalaman dapat didahului dengan identifikasi penyebaran perairan pedalaman di wilayah perairan nusantara [Pasal 50 UNCLOS] disertai dengan identifikasi sumber daya alam hayati dan non hayati yang dapat dikembangkan dan kemudian memetakan perairan pedalaman tersebut ke dalam suatu peta tematik.

Berikutnya adalah penelitian ilmiah kelautan terhadap batas-batas perairan nusantara yang terdiri dari garis pangkal kepulauan dan batas perairan pedalaman yang terletak di perairan nusantara [Pasal 50 UNCLOS]. Penelitian ilmiah kelautan di perairan nusantara sudah banyak dilakukan dan bahkan sudah menghasilkan hasil-hasil pembangunan seperti minyak dan gas bumi. Walaupun demikian, penelitian tersebut perlu terus dilanjutkan dan ditingkatkan. Penelitian juga perlu dikembangkan terhadap masalah-masalah yang belum memperoleh perhatian secara proporsional seperti hak-hak perikanan tradisiona ${ }^{15}$ dan kabel bawah laut [Pasal 51 UNCLOS] serta alur-alur laut kepulauan Indonesia (ALKI) [Pasal 53 UNCLOS].

Penelitian ilmiah kelautan terhadap laut teritorial dapat difokuskan pada batas luar selebar 12 mil laut diukur dari garis pangkal kepulauan, khususnya yang terletak di wilayah laut perbatasan berserta penegakan kedaulatannya. Penegakkan kedaulatan di laut teritorial dapat diperkuat dengan penetapan zona tambahan selebar 24 mil laut diukur dari garis pangkal kepulauan atau 12 mil laut dari batas luar laut teritorial [Bagian II (Pasal 2-Pasal 33) UNCLOS]. Di zona tambahan, Indonesia memiliki jurisdiksi untuk melakukan pengawasan guna mencegah pelanggaran kepabeanan, fiskal, imigrasi, dan sanitari. Indonesia sampai saat ini belum memutuskan untuk mendeklarasikan zona tambahan. Apa bila dideklarasikan, zona tambahan tersebut akan memberikan banyak manfaat kepada Indonesia. Dalam kaitan ini, hasil penelitian ilmiah kelautan dapat menggambarkan batas-batas, posisi, status hukum, dan manfaat zona tambahan, serta dapat memberikan pertimbangan-pertimbangan geografis, oceanografis, geologis, ekonomi, sosial, dan politik kepada pemerintah guna mendukung upaya deklarasi.

Pada batas luar zona tambahan melakat ZEE selebar 200 mil laut diukur dari garis pangkal kepulauan. Lebar ZEE yang sesungguhnya adalah 176 mil laut diukur dari batas luar zona tambahan. Status hukum ruang air zona tambahan dan ZEE adalah laut lepas (high sea) di mana berlaku kebebasan laut lepas (the freedom of the high sea). Indonesia di kedua zona tersebut mempunyai hakhak berdaulat (sovereign rights) atas sumber daya alam, pendirian dan penggunaan bangunan/pulaupulau buatan, penelitian ilmiah kelautan, serta perlindungan dan pelestarian lingkungan laut [Pasal 56 jo. Pasal 58 UNCLOS]. Penelitian ilmiah kelautan diZEE perlu difokuskan pada tata letak dan pemetaan batas luar ZEE Indonesia, batas ZEE antara Indonesia dan negara tetangga, hak-hak dan kewajiban Indonesia, serta hak-hak dan kewajiban negara lain di ZEE Indonesia.

Dasar laut di bawah laut teritorial, zona tambahan, dan ZEE Indonesia merupakan landas kontinen Indonesia sebagai kepanjangan alamiah (natural prolongation) daratan pulau-pulau Indonesia. Penelitian ilmiah kelauatan hendaknya difokuskan pada batas luar landas kontinen, termasuk landas kontinen di wilayah laut perbatasan. Batas luar landas kontinen mencakup batas yang berimpit dengan ZEE bila di perairan pantai landas kontinen langsung curam dan batas luar yang ditengarai oleh continental slope atau continental rise pada landas kontinen yang landai [Pasal 76 UNCLOS].

\section{Wilayah Laut Perbatasan}

Posisi negara kepulauan Indonesia berbatasan langsung di laut dengan 10 negara tetangga, sehingga terbentuklah 10 wilayah laut perbatasan. Batas wilayah laut yang perlu

\footnotetext{
${ }^{15}$ Marhaeni Ria Siombo, 2010, Hukum Perikanan Nasional dan Internasional, Jakarta, Gramedia, hlm. 54-56.
} 
diselesaikan mencakup batas-batas laut teritorial, ZEE, dan landas kontinen. Kesepuluh wilayah laut pertabasan tersebut meliputi: ${ }^{16}$

a. Wilayah laut perbatasan antara Indonesia dan India di Laut Andaman;

b. Wilayah laut perbatasan antara Indonesia dan Thailand di bagian utara Selat Malaka;

c. Wilayah laut perbatasan antara Indonesia dan Malaysia di Selat Malaka, Selat Singapura, Laut China Selatan, dan Laut Sulawesi;

d. Wilayah laut perbatasan antara Indonesia dan Singapura di Selat Singapura;

e. Wilayah laut perbatasan antara Indonesia dan Vietnam di Laut China Selatan;

f. Wilayah laut perbatasan antara Indonesia dan Pilipina di Laut Sulawesi;

g. Wilayah laut perbatasan antara Indonesia dan Guam (Amerika Serikat) di Samudera Pasifik;

h. Wilayah laut perbatasan antara Indonesia dan Papua New Guinea di Samudera Pasifik dan di Laut Arafura;

i. Wilayah laut perbatasan antara Indonesia dan Australia di Laut Arafura dan Samudera Hindia;

j. Wilayah laut perbatasan antara Indonesia dan Timor Leste di Selat Wetar dan Samudera Hindia.

Penelitian ilmiah kelautan di wilayah laut perbatasan perlu difokuskan pada batas-batas wilayah laut yang sudah dan yang belum diselesaikan. Prinsip-prinsip penyelasaian batas wilayah laut antar negara meliputi:

a. Prinsip garis tengah (median line principle) untuk menyelesaikan batas wilayah laut dua negara yang saling berhadapan dengan memperhatikan faktor-faktor fisik seperti geografi dan geologi;

b. Prinsip sama jarak (equidistance principle) untuk menyelesaikan batas wilayah laut dua negara yang berdampingan dengan memperhatikan faktor-faktor fisik seperti geografi dan geologi;

c. Prinsip keadilan (equitable principle) untuk menyelesaikan batas wilayah laut dua negara, baik yang berhadapan maupun yang berdampingan, dengan mengutamakan perhatiannya pada faktor-faktor non-fisik seperti ekonomi dan sosial;

d. Prinsip kepanjangan alamiah sifat fisik daratan (natural prolongation principle) untuk menyelesaikan batas landas kontinen dua negara yang berhadapan atau berdampingan dengan memperhatikan faktor-faktor fisik geologi dan geografi.

Penerapan prinsip-prinsip tersebut dalam penyelesaian garis batas wilayah laut antara Indonesia dengan negara tetangga adalah sebagai berikut:

a. Penyelesaian batas landas kontinen antara Indonesia dan Vietnam di Laut China Selatan : Indonesia mempergunakan median line principle dan Vietnam mempergunakan natural prolongation principle. Berdasarkan adanya palung sungai di dasar laut (thalweg) dan endapan lumpur sebagai kelanjutan alamiah dari Sungai Mekong sampai ke Pulau Natuna, maka Vietnam mengklaim bahwa landasan kontinennya membentang dari muara Sungai Mekong sampai ke Pulau Natuna. Pertautan dua prinsip tersebut mengindikasikan bahwa wilayah landas kontinen yang dirundingkan adalah wilayah landas kontinen yang berada di antara garis tengah dan Pulau Natuna.

b. Penyelesaian batas ZEE antara Indonesia dan Pilipina di Laut Sulawesi: Indonesia mempergunakan median line principle dan Pilipina mempergunakan equitable principle. Pilipina mengklain bahwa wilayah ZEE-nya adalah wilayah penangkapan ikan tradisional dari

${ }^{16}$ Achmad Jusnadi, Herie Saksono dan Suryo Sakti, 2005, Platform Penanganan Permasalahan Perbatasan Antar Negara, Jakarta, Direktorat Wilayah Administrasi dan Perbatasan, Direktorat Jenderal Pemerintahan Umum, Departemen Dalam Negeri, hlm. 29-39. 
Tommy Hendra P., Penelitian Ilmiah Batas Wilayah Laut Indonesia

nelayan-nelayannya yang melengkung ke wilayah ZEE Indonesia. Masing-masing pihak masih bertahan pada posisi masing-masing, sehingga sampai saat ini batas ZEE kedua negara belum terselesaikan.

c. Penyelesaian batas landas kontinen antara Indonesia danAustralia di selatan Pulau Timor: Indonesia mempergunakan median line principle dengan dukungan data guratan geologi dari utara ke selatan dan Australia memakai natural prolongation principle dengan dukungan data guratan geologi dari timur ke barat. Data geologi yang dipergunakan oleh Indonesia dimaksudkan untuk menunjukkan tidak adanya kelanjutan alamiah (natural prolongation) baik antara Pulau Timor maupun Benua Australia dengan landas kontinen. Namun ternyata Australia telah mempergunakan data guratan geologi timur-barat yang umurnya lebih tua dari guratan geologi utara-selatan. Data guratan geologi timur-barat tersebut Australia menunjukkan bahwa landas kontinen yang sedang dirundingkan merupakan kelanjutan alamiah dari Benua Australia. Hasil akhir perundingan antara Indonesia dan Australia adalah kesepakatan Timor Gap sebagai batas landas kontinen kedua negara.

\section{Wilayah Laut Daerah}

UU Nomor 5 Tahun 1974 tentang PokokPokok Pemerintahan di Daerah tidak mengatur kewenangan pemerintah daerah atas wilayah laut. Sebagai konsekuensinya, pemerintah daerah tidak dapat berpartisipasi aktif di dalam pembangunan kelautan. Untuk mengatasi masalah ini, UU Nomor 5 Tahun 1974 diganti dengan UU Nomor 22 Tahun 1999 dan kemudian diganti lagi dengan UU Nomor 32 Tahun 2004 tentang Pemerintahan Daerah yang memberi jurisdiksi atas wilayah laut tertentu kepada daerah. Pemerintah provinsi memiliki kewenangan atas wilayah laut selebar 12 mil laut yang diukur dari garis pantai, sedang pemerintah kabupaten/kota mempunyai kewenangan atas wilayah laut selebar
$1 / 3$ (satu per tiga) dari lebar wilayah laut provinsi. Penetapan batas wilayah laut antar daerah yang berhadapan dilakukan dengan menerapkan prinsip garis tengah dan antar daerah yang berdampingan dengan menggunakan prinsip sama jarak. Penetapan dan pemetaan batas-batas wilayah laut daerah sangat memerlukan dukungan penelitian ilmiah kelautan. Batas-batas wilayah laut daerah sampai saat ini belum ditetapkan. Sebagai akibatnya, pelaksanaan pembangunan kelautan oleh pemerintah daerah belum dapat terselenggara secara optimal.

\section{Wilayah Archipelago}

Negara kepulauan adalah suatu negara yang secara keseluruhan terdiri dari satu atau beberapa kepualauan (archipelago) dan dapat juga mencakup pulau-pulau lainnya [Pasal 46 huruf(a) UNCLOS]. Wilayah negara kepulauan disebut sebagai wilayah archipelago [Pasal 46 huruf (b) UNCLOS]. Penelitian ilmiah kelautan tentang ciri-ciri wilayah archipelago akan dapat memperkuat eksistensi NKRI sebagai negara kepulauan terbesar di dunia dan memberikan argumentasi ilmiah tentang perlunya untuk meningkatkan UU Nomor 6 Tahun 1996 tentang Perairan Indonesia menjadi UU yang mengatur Wilayah Kepulauan Indonesia. Berdasarkan UU Wilayah Kepualauan tersebut, setiap kebijakan nasional pemerintah haruslah berbasis kepulauan.

\section{Simpulan}

Satu kesatuan wilayah laut Indonesia baru terwujud pada saat UNCLOS diberlakukan dan mengikat secara internasional pada tahun 1994. Namun demikian, batas-batas luar wilayah laut tersebut belum seluruhnya selesai ditetapkan. "pagar" wilayah NKRI masih banyak "lubang-lubangnya." Masih banyak garis batas wilayah laut perbatasan dengan negara tetangga yang perlu diselesaikan melalui perundingan. Penyelesaian batas-batas tersebut perlu didukung dengan penelitian ilmiah kelautan tentang batas-batas wilayah laut Indonesia. Hasil penelitian akan memberi kejelasan tentang prinsip-prinsip mana yang perlu dipergunakan dalam perundingan dengan negara tetangga. Terselesaikannya batas-batas tersebut memungkinkan Indonesia menegakkan kedaulatan 
dan hak-hak berdaulatnya di laut sehingga pembangunan kelautan dapat diselenggarakan secara optimal dan berkelanjutan untuk sebesarbesar kemakmuran rakyat Indonesia.

\section{DAFTAR PUSTAKA}

\section{Buku}

Churchill, R.R. and A.V. Lowe, 1999, The Law of the Sea, Manchester: Manchester University Press.

Jusnadi, Achmad, Herie Saksono dan Suryo Sakti, 2005, Platform Penanganan Permasalahan Perbatasan Antarnegara, Jakarta: Direktorat Wilayah Administrasi Perbatasan, Direktorat Jenderal Pemerintahan Umum, Departemen Dalam Negeri.

Kusumaatmadja, Mochtar, 1995, Masalah Lebar

Laut Teritorial Pada KonperensiKonperensi Hukum Laut Jenewa (1958 dan 1960), Bandung: Pusat Studi Wawasan Nusantara, Hukum dan Pembangunan.

Kusumaatmadja, Mochtar, 1995, Hukum Laut Internasional, Bandung: Pusat Studi Wawasan Nusantara, Hukum dan Pembangunan.

Kusumaatmadja, Mochtar, 1995, Bunga Rampai Hukum Laut, Bandung: Pusat Studi Wawasan Nusantara, Hukum dan Pembangunan.

Patlis, Jason M., et. al., 2005, Мепијu Harmonisasi Sistem Hukum Sebagai Pilar Pengelolaan Wilayah Pesisir Indonesia, Jakarta: KPPN/BAPPENAS, DKP, DH\&HAM, dan USAID.

Prescott, J.R.V., 1985, The Maritime Political Boundaries of the World, London: Methuen. Siombo, Marhaeni Ria, 2010, Hukum Perikanan Nasional dan Internasional, Jakarta: Gramedia Pustaka Utama.

Sumardiman, Adi, et.al., 1982, Wawasan Nusantara, Jakarta: Surya Indah.

Sumardiman, Adi, 1992, Wilayah Indonesia dan Dasar Hukumnya, Jakarta: Pradnya Paramita.
Wibowo, Antonius P.S., 2000, Menyambut Sistem Kelautan Indonesia Baru, Jakarta: Atma Jaya.

Jurnal

Purwaka, Tommy Hendra, "Paradigmn Shift in the Implementation of the Law of the Sea in Indonesia," Indonesian Journal of International Law, Volume 8, Number 1, October 2010.

\section{Konvensi}

United Nations, 1983, United Nations Convention on the Law of the Sea, New York: United Nations Publication.

\section{Undang-Undang}

Undang-Undang Dasar Negara Republik Indonesia Tahun 1945.

UU Nomor 4 Prp Tahun 1960 tentang Perairan Indonesia.

UU Nomor Nomor 19 Tahun 1961 tentang Ratifikasi atas Tiga Konvensi Jenewa Tahun 1958. UU Nomor 2 Tahun 1971 tentang Pengesahan Hasil Perundingan Garis Batas Laut Wilayah Bersama Antara Indonesia Dengan Malaysia di Selat Malaka. UU Nomor 1 Tahun 1973 tentang Landas Kontinen Indonesia

UU Nomor 6 Tahun 1973 tentang Pengesahan Hasil Perundingan Garis-Garis Batas Tertentu Antara Indonesia Dengan Papua New Guinea.

UU Nomor 7 Tahun 1973 tentang Pengesahan Hasil Perundingan Garis-Garis Batas Tertentu Antara Indonesia Dengan Singapura di Selat Singapura. UU Nomor 4 Tahun 1975 tentang Pokok-Pokok Pemerintahan di Daerah

UU Nomor 5 Tahun 1983 tentang Zona Ekonomi EksklusifIndonesia.

UU Nomor 17 Tahun 1985 tentang Ratifikasi Konvensi PBB 1982 Tentang Hukum Laut.

UU Nomor 6 Tahun 1996 tentang Perairan Indonesia.

UU Nomor 22 Tahun 1999 tentang Pemerintah Daerah.

UU Nomor 32 Tahun 2004 tentang Pemerintah Daerah. 